\title{
WHAT HAS BEEN WRONG WITH THE RETIREMENT RULES IN HUNGARY?
}

\author{
Tibor CZEGLÉDI - András SIMONOVITS - Endre SZABÓ - Melinda TIR*
}

(Received: 8 November 2016; revision received: 24 February 2017;

accepted: 18 March 2017)

\begin{abstract}
A basic problem with the ever-changing Hungarian retirement rules has been that they created excessive shares of gainers and of losers. Certain workers with long (and continuous) employment could retire well below the normal retirement age (NRA) with full benefit. Other workers, with fragmented and therefore short employment had to work until reaching the ever rising NRA. A peculiar consequence of these rules is the strong negative correlation between the retirement age and the length of contribution. Moving in the direction of a fair system, like the Nonfinancial Defined Contribution system, would improve sustainability and fairness.
\end{abstract}

Keywords: normal retirement age, early retirement, years of contributions, rights, flexible (variable) retirement

JEL classification indices: H55, I14, J26

* We express our debt to the experts of the Central Administration of National Pension Insurance who created a very detailed dataset for the public; and to Nick Barr, Rudolf Borlói, Róbert Iván Gál, Gábor Kézdi, Ádám Reiff and the three anonymous referees for their valuable comments. András Simonovits' research was supported by the Hungarian Research Fund (OTKA), Grant no. 108668.

András Simonovits, corresponding author. Research Adviser at the Institute of Economics, Research Center for Economics and Regional Sciences, Hungarian Academy of Sciences. E-mail: simonovits.andras@krtk.mta.hu

Tibor Czeglédi, Data Bank, Research Center for Economics and Regional Sciences, Hungarian Academy of Sciences. E-mail: czegledi.tibor@krtk.mta.hu

Endre Szabó, Data Bank, Research Center for Economics and Regional Sciences, Hungarian Academy of Sciences. E-mail: szabo.endre@krtk.mta.hu

Melinda Tir, Data Bank, Research Center for Economics and Regional Sciences, Hungarian Academy of Sciences. E-mail: tir.melinda@krtk.mta.hu 


\section{INTRODUCTION}

During the transition from a command economy to a market economy, the Hungarian pension system has evolved frequently in confusing ways. In the 1990s, the system had to be adapted to the collapse of employment and rising inflation. Following the World Bank suggestions, in 1998 the government partially privatised the public pension system and strengthened the role of defined contribution in the remaining dominant public pillar. Under the influence of the Great Recession, a new government practically renationalised the mandatory private pillar in 2011.

Anticipating the long-term population aging, subsequent Hungarian governments raised the normal female/male retirement age step by step from 55/60 (1996) to 62 (by 2009 and 2001, respectively) and legislated further increases from 62 to 65 (by 2022). Fearing unemployment, however, the deduction for early retirement was too low and frequently zero for those workers who had a long enough contribution (37-40 years), including years spent in education and raising children. Since 2011/2012, the present government eliminated early retirement for all males and for those females who had less than 40 years of rights, while opening the way for early retirement without deduction for those females who had at least 40 years of rights, called Females 40 (Table A3.1 summarises the most important parametric changes.) As a result, the effective retirement age has not risen enough (Table 8) and the fairness, to be defined later, has even decreased further.

Though the issues of the two previous paragraphs are loosely related, we shall separate them. The bulk of the Hungarian literature focused its attention on the problems mentioned in paragraph 1 and hardly paid attention to the problems mentioned in paragraph 2. In contrast, in the present paper, we skip the problems of the benefit-wage schedule and concentrate on the issues of impact of the retirement rules.

Our main results are as follows: (i) using a very simple theoretical model with an average earning path, we define the gainers and losers of various theoretical and existing (Hungarian) pension schemes with respect to an ideal nonfinancial defined contribution (NDC) system or its linearised version; (ii) calculating theoretical and empirical correlation coefficients between retirement age and the length of contribution, we argue that negative values indicate unfair retirement rules. Here we only name two extreme types: females working 40 years and retiring at age 58 (gainers), and females working 39 years, but not allowed to retire at age 61 (losers) in 2013, who will not be allowed to retire at age 64 in 2022.

We are convinced that the current rigid/exceptional system - which is almost a singularity in the international scene - should be replaced by a flexible (variable) retirement system as soon as possible. Further work is needed to determine 
the socially optimal values of the parameters of the Hungarian pension system: the earliest retirement age, the deduction for early retirement, and the bonus for delayed retirement. Note that we speak of flexible retirement if adding a year to the length of contributions or to the retirement age strongly increases the retirement benefit, opening the way to the flexible choice of the retirement age like the $\mathrm{NDC}^{1}$, where the annual benefit is approximately equal to the ratio of the lifetime contributions to the remaining life expectancy. A further flexibility is provided by the partial retirement: two retirement ages exist, and between them, the workers only work part-time and receive corresponding partial pensions.

The Hungarian public pension system has been critically analysed in a number of publications (e.g. Augusztinovics et al. 2002 and Simonovits 2008). Augusztinovics - Köllö $(2008,2009)$ documented the detrimental impact of fragmented working paths on the corresponding pension benefits. Cseres-Gergely (2008) studied the role of incentives in early retirement. Molnár - Hollós Marosi (2015) presented data showing the dependence of life expectancy on the wage/benefit and the retirement age. In parallel to Bajkó et al. (2015), Freudenberg et al. (2016) considered the long-term impact of recent reforms, including that of the retirement rules. According to the latter estimates, the rise of the normal retirement age plus the elimination of early retirement reduce the pension deficit by $0.5 \%$ of the GDP, while the introduction of Females 40 increases the deficit by the same amount.

We relegate the classical literature to a footnote ${ }^{2}$ and turn to the new wave of papers concentrating on other dimensions of the retirement problem from the US as well as EU. For example, Chan - Stevens (2004) looked for an answer to the question, "How does job loss affect the timing of retirement?". Staubli - Zweimüller (2013) and Manoli - Weber (2016) studied a similar question, "Does raising the early retirement age increase employment of older workers?". Perhaps the clos-

1 Though we call the NDC an ideal system in this paper, we must signal that it also has pitfalls. The government does not know or does not want to know the dependence of life expectancy on the retirement age and the lifetime average wage (for example, within a given sex, it does not know that the retirement age signals the expected remaining life and with good reason, it does not want to know the mortality difference between males and females). Therefore, the traditional insurance rules are not fair (see, for example, Eső - Simonovits 2002; Diamond 2003; Eső et al. 2011; Krémer 2015), but here we neglect this complication.

2 Gustman - Steinmeier (1986) published a structural model of retirement to the US public pension system, assuming that retirees maximise their lifetime utility functions. Considering the interaction of the Social Security and the private pension system with defined benefit, Stock - Wise (1990) were able to explain the emergence of two peaks around the earliest and the normal retirement ages (62 and 65). Rust - Phelan (1997) analysed a standard model of retirement behaviour under the influence of Social Security and Medicare and private wealth. The volume edited by Gruber - Wise (2007) provides a good survey on the topic. 
est to our paper is Etgeton (2016), entitled "Labor Market Frictions, Retirement and Inequality". We only quote one observation (from the abstract): "widespread reform effectiveness is hampered by the heterogeneous availability of jobs."

The structure of the remaining part of the paper is as follows: Section 2 models flexible (variable) pension systems. Section 3 moves to the earlier permissive Hungarian system, and Section 4 continues with the present (exceptional/rigid) one. Section 5 draws the conclusions. Three appendices complete the paper: $A p-$ pendix 1 formally defines the welfare ranking of any two systems and the partial retirement. Appendix 2 illustrates the dependence of the correlation coefficient and the welfare on the fairness of the system in a numerical model. Appendix 3 contains important general Hungarian statistics, also used to transform numbers from absolute into relative values in the main text.

\section{FLEXIBLE (VARIABLE) SYSTEM}

First, we outline the general framework and then analyse two types of flexible (variable) systems: the so-called nonfinancial defined contribution system and the linear benefit rule.

\subsection{Framework}

In every pension system, three main individual variables determine the benefit: the length of contribution $S$, the retirement age $R$, and the average lifetime gross wage $w .^{3}$ To simplify the analysis, we work with constant prices and wages. Sometimes we only consider a single cohort. We shall generally skip disability or survivor beneficiaries, but in Tables 3 and 4, in addition to the old-age pensioners, the former category is also considered and disability is taken into account.

First, we need a function, connecting average lifetime gross and net wages: $v$ $=T(w)$. In Hungary, this function is proportional: $v=\theta w,(\theta=0.66)$ in 40 years, but now it is still strongly progressive (concave), and this special feature strongly influences the initial benefits and benefits in payment. In calculating fairness, $b(R, S, T(w))$ is the corresponding benefit function. We should take into account

3 Years of contribution contain years at higher studies and raising small children. In reality, when the ratio of own wage to average wage varies annually, the rules are more complicated, but we skip this complication. 
that the expected remaining life expectancy at age $R$ also depends on the gross average lifetime wage $w: e_{R, w}{ }^{4}$

Assuming that the pension contribution is proportional to the gross wage (i.e. by neglecting the cap on the contribution base effective between 1993 and 2012), and denoting the presumptive time-invariant contribution rate by $\tau$, the expected lifetime balance of type $(R, S, w)$ is given by

$$
d(R, S, w)=\tau w S-b(R, S, T(w)) e_{R, w} .
$$

\subsection{Nonfinancial defined contribution (NDC) system}

For an NDC (denoted by index $I$ for ideal), the expected lifetime balance is zero for every type, therefore the pension rule is defined as

$$
b_{I}(R, S, T(w))=\tau w S / e_{R, w}, \text { where } S \geq S_{\mathrm{m}} \text { and } R \geq R_{\mathrm{m}},
$$

$S_{\mathrm{m}}=$ minimum length, $R_{\mathrm{m}}=$ minimum (earliest) retirement age; note that here the normal retirement age $R^{*}$ does not play any role.

Even in the NDC, the dependence of $e_{R, w}$ on $w$ is neglected, rather it is simply assumed that $e_{R, w}=e_{R}$, therefore (2) is replaced by

$$
b_{I}(R, S, T(w))=\tau w S / e_{R} .
$$

As a side remark, we note that the estimation of the expected life span at retirement is a very difficult problem and in the past decades, $e_{R}$ was typically significantly underestimated.

Turning to imperfect systems, it is worth defining the gainers and losers in a system $M$ with respect to the ideal system $I$. We have no structural parameters characterising the various types, therefore we distinguish and index types as points of a sufficiently fine 3 -dimensional grid: $i=1,2, \ldots, n ;\left(R_{i}(\mathrm{I}), S_{i}(\mathrm{I}), w_{i}\right)$ are compared to the alternative outcomes $\left(R_{i}(\mathrm{M}), S_{i}(\mathrm{M}), w_{i}\right)$.

We can give more than one definition for the gainers and losers.

(1) With respect to the annual benefit, system $M$ is better than system $I$ for type $i$, if and only if type $i$ receives higher benefit in $M$ than in $I$ for outcome $\left(R_{i}(\mathrm{M})\right.$, $\left.S_{i}(\mathrm{M}), w_{i}\right)$ :

$$
b_{\mathrm{M}}\left(R_{i}(\mathrm{M}), S_{i}(\mathrm{M}), w_{i}\right)>b_{\mathrm{I}}\left(R_{i}(\mathrm{M}), S_{i}(\mathrm{M}), w_{i}\right) .
$$

4 We do not denote that this parameter characterises a given cohort $t$, for example, those born in year $t$. As is well known, this life expectancy increases with the wage and decreases with the age, but more slowly than the age increases. 
Remark. If the comparison is made on the basis of $I$ rather than $M$, the corresponding condition $b_{\mathrm{M}}\left(R_{i}(\mathrm{I}), S_{i}(\mathrm{I}), w_{i}\right)>b_{\mathrm{I}}\left(R_{i}(\mathrm{I}), S_{i}(\mathrm{I}), w_{i}\right)$ may not hold.

(2) With respect to the net contribution, or lifetime balance, system $M$ is better than system $I$ for type $i$, if and only if her net balance is negative for the outcome:

$$
d_{\mathrm{M}}\left(R_{i}(\mathrm{M}), S_{i}(\mathrm{M}), w_{i}\right)<0 .
$$

Remark. As before, it is not guaranteed that $d_{\mathrm{M}}\left(R_{i}(\mathrm{I}), S_{i}(\mathrm{I}), w_{i}\right)<0$ also holds.

The third definition will be given in Appendix 1 later.

\subsection{Linear flexible system}

Formula (2) is further simplified, namely linearised in other cases and gross wage is replaced by net wage. For a given earning and length of contribution, the net (i.e. after tax) benefit is an increasing linear function of the retirement age:

$$
b(R, S, w)=\left[1+\delta\left(R-R^{*}\right)\right] \gamma S T(w),
$$

where $R^{*}, \delta$, and $\gamma$ are positive constants.

$R^{*}$ is the normal retirement age, $R_{\mathrm{m}}<R^{*}<R_{\mathrm{M}}, \delta$ is the delayed/early retirement coefficient, and $\gamma$ is the constant accrual rate in terms of the net average wage. Here it is not self-evident that the net balance is identically zero: $d(R, S$, $w) \equiv 0$, therefore we have to require that at least their expected value be zero. Let $p_{R, S, w}>0$ be the relative share of type $(R, S, w)$, their sum is being equal to 1 . By definition, in a balanced pension system, the expected value of the net balances is zero:

$$
\sum p_{R, S, w} d(R, S, w)=0
$$

Inserting equation (1) and (3) into (4) yields a condition for the system is balanced:

$$
\sum p_{R, S, w}\left\{\tau w-\left[1+\delta\left(R-R^{*}\right)\right] \gamma T(w) e_{R, w}\right\} S=0 .
$$

We do not consider the problem of balance when it is taken for the whole population rather than a single cohort. Accepting ex post analysis, a simple equation is obtained for either the accrual rate $\gamma$ or the contribution rate $\tau$ : 


$$
\tau \sum p_{R, S, w} w S=\gamma \sum p_{R, S, w}\left[1+\delta\left(R-R^{*}\right)\right] T(w) S e_{R, w}
$$

To avoid arbitrariness, we have to stipulate that in a genuinely flexible system, the normal retirement age $R^{*}$ lies years above the minimum retirement age $R_{\mathrm{m}}$, years below the maximum retirement age $R_{\mathrm{M}}$ and the delayed retirement coefficient $\delta$ is several percent/year. Moreover, there may be a malus $\delta_{1}$ and a bonus $\delta_{2}$ for early and delayed retirement, respectively, rather than a uniform $\delta$.

Table 1 displays the linear flexible benefits for selected contribution lengths and retirement ages, calculating with the normal retirement age (NRA) of 62 valid in Hungary until 2012, with $\delta_{1}=0.03$ and $\delta_{2}=0.06$. For example, if somebody retires at age 60 with 38 years of service, he/she receives $71.6 \%$ of his/her net earning. The benefit in the cell $(58,40)$ is only $70.4 \%$. We shall base our evaluation of the distortion caused in the exemptional/rigid system in Table 7 on this calculation.

Table 1. Linear flexible benefits - retirement ages and length of contribution

\begin{tabular}{l|c|c|c|c|c}
\hline $\begin{array}{l}\text { Years of contribution, } S \\
\text { Retirement age, } R\end{array}$ & 36 & 38 & 40 & 42 & 44 \\
\hline 58 & 0.634 & 0.669 & 0.704 & 0.739 & 0.774 \\
\hline 60 & 0.677 & 0.714 & 0.752 & 0.790 & 0.827 \\
\hline 62 & 0.720 & 0.760 & 0.800 & 0.840 & 0.880 \\
\hline 64 & 0.806 & 0.851 & 0.896 & 0.941 & 0.986 \\
\hline 66 & 0.893 & 0.942 & 0.941 & 1.042 & 1.091 \\
\hline
\end{tabular}

Note: In terms of net wage. Model calculations.

Rising real earnings and price indexation together may complicate the picture. ${ }^{5}$

\section{SYSTEM WITH EXEMPTION (HUNGARY UNTIL 2011)}

We shall relate the system with exemption prevailing in Hungary until 2012 to the foregoing flexible system. Unlike in (3), the value of $\delta$ was a sophisticated function of the length of contribution:

5 If in year $t$, a worker retires at age $R$ with contribution length $S$, and average lifetime gross wage $w_{t}$, his/her benefit is equal to $b_{t}\left(R, S, T\left(w_{t}\right)\right)$. Calculating with full employment for the last year, due to a delay of one year, his/her new initial benefit would be equal to $b_{t}(R+1, S+1$, $\left.T\left(w_{t+1}\right)\right) g_{t+1}$, where $g_{t+1}$ is the growth factor of the net wage from year $t$ to $t+1$. Applying the pure price indexation, the new benefit should be compared to $b_{t}\left(R, S, T\left(w_{t}\right)\right)$. The delay raises the yield of any extra year $g_{t+1}-1$, except during the period 2013-2015, when the overindexation of pensions in payment amounted to $8 \%$. 


$$
b(R, S, w)=\left[1+\delta_{S}\left(R-R^{*}\right)\right] \gamma S T(w),
$$

where $\delta_{S}$ is a non strictly decreasing function of the length of contribution: $\left(S=S_{\mathrm{m}}, . ., S_{\mathrm{o}}\right), \delta_{S \mathrm{o}}=0$, where $S_{\mathrm{o}}$ is the critical value of the length of contribution (e.g. 35 or 40 years), implying full benefits.

In such a system with exemption, almost every worker retired as soon as it was possible, i.e. when he/she reached the prescribed critical length of contribution $S_{\text {o }}$. As is obvious, in such a system, working until NRA hardly increases the benefit, but lifts the net balance of contribution, causing a loss to the worker.

By the way, we can obtain a more precise description about this system, if we replace $\gamma S$ by a more complex series $\left(c_{S}\right)$, representing the accumulated accrual rates. Table 2 displays the selected values, between the subsequent benching points, the function is a linear one (row 2). For example, $c_{S}=0.02 S$ for $40 \leq S \leq$ 50 , but for $S \geq 50, c_{S}=1$ (constant); below 40, its slope changes haphazardly. For example, for $S$ lying between 36 and $40, c_{S}=0.74+0.015(S-36)$. Row 3 gives a hypothetical proportional scheme. In addition, the series of valorised net wages $\left(v_{t}\right)$ and their progressive (concave) average also play a role.

Table 2. Accumulated accrual rates

\begin{tabular}{l|c|c|c|c}
\hline $\begin{array}{l}\text { Length of contribution }(S) \\
\text { Replacement }\end{array}$ & 20 & 25 & 36 & 40 \\
\hline Actual $\left(c_{S}\right)$ & 0.53 & 0.63 & 0.74 & 0.80 \\
\hline Proportional $(\gamma S)$ & 0.40 & 0.50 & 0.72 & 0.80 \\
\hline
\end{tabular}

Note: In terms of (lifetime valorised) net wage. Official data.

In addition to these factors, due to changing rules, the parameter values in equation (3') also depend on the calendar year, but for the time being, this dependence is neglected. In the Hungarian practice, the length of contribution is downward rounded-off from month to years, but the retirement age is given in months. The benefit also depends on gender ( $\mathrm{f}=$ female, $\mathrm{m}=$ male).

The simplest tool to characterise the distortion, due to the system with exemption, is the paradoxically negative correlation between the length of contribution and the retirement age. We recall the definition of the correlation coefficient between two random variables. Let $R$ and $S$ be random variables of the retirement age and of the length of contribution, $\mathbf{E} R$ and $\mathbf{E} S$ their expected values, and $\mathbf{D} R$ and $\mathbf{D} S$ their standard deviations, respectively. In this case, their coefficient of correlation is defined as $\rho(R, S)=\mathbf{E}[(R-\mathbf{E} R)(S-\mathbf{E} S)] /[\mathbf{D} R \mathbf{D} S]$. As is known, this index lies between -1 and 1 . For a negative correlation, the decrease in the index shows the strengthening of the correlation. In the usual one-dimensional 


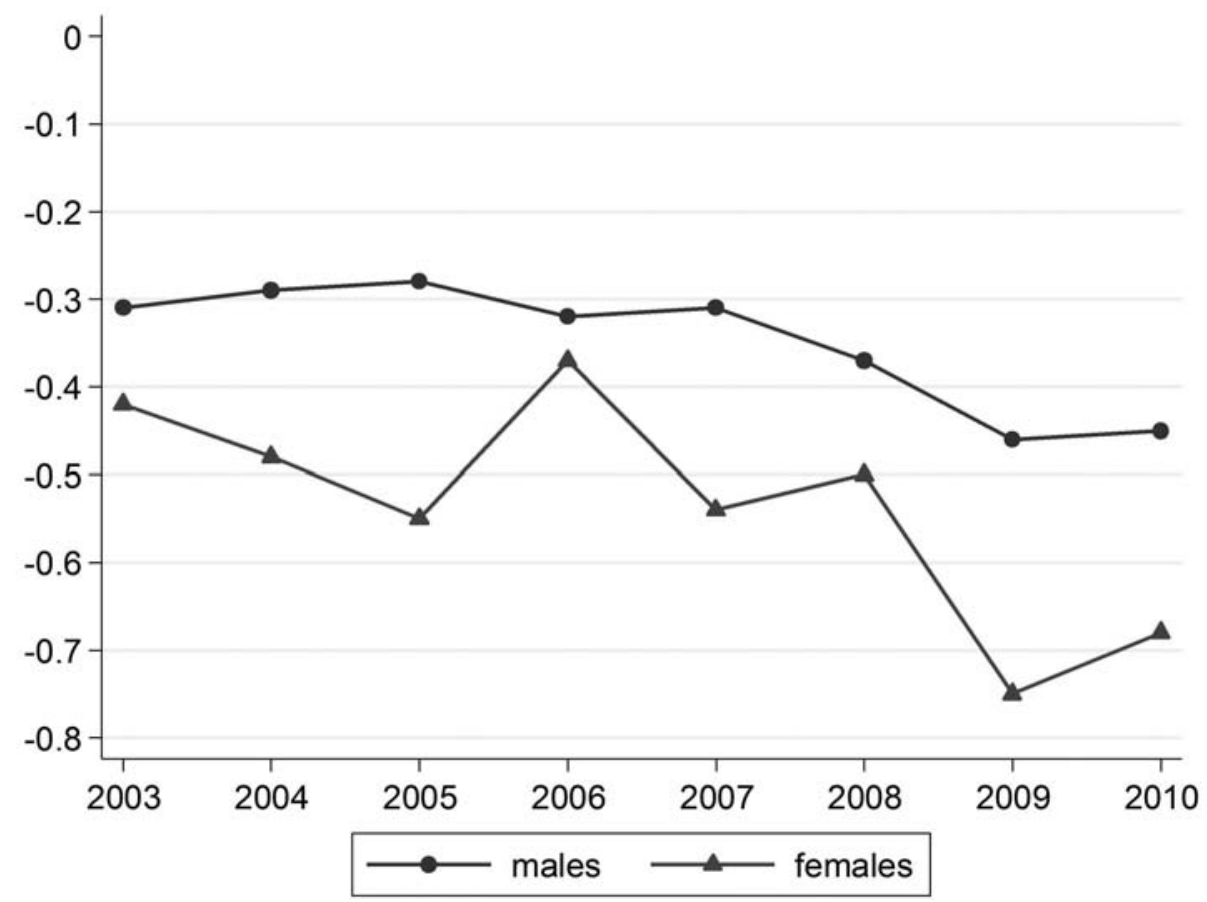

Figure 1. Correlation for those retiring above 54, between 2003 and 2010

framework, we expect strong positive correlation, but in reality, the correlation is negative (for theoretical details, see Appendix 2). Making our Figures 1-3, we relied on data base "Nyugdmeg", 6 containing the aggregated pension decisions for the period 2003-2010.

According to Figure 1, the foregoing male correlation was "only" -0.3 in 2003 , but it dropped to -0.45 by 2007 . For females, the situation is even more paradox: it started from -0.4 and dropped to -0.7 by 2010 . This is a sign of the strengthening impact of the exemption, neutralising the benevolent impact of the rising normal retirement age.

To exclude outliers, we confine our attention to those who had at least 20 years of contribution (the recent minimum value). Similarly to Figure 1, Figure 2

6 Database "Nyugdmeg" contains the retirement decisions concerning the period 1999-2010, aggregated according to birth year, retirement year and month, gender, length of contribution, average pension, and the valorised net earning. Access to these data can be required from the Central Administration of National Pension Institute. 


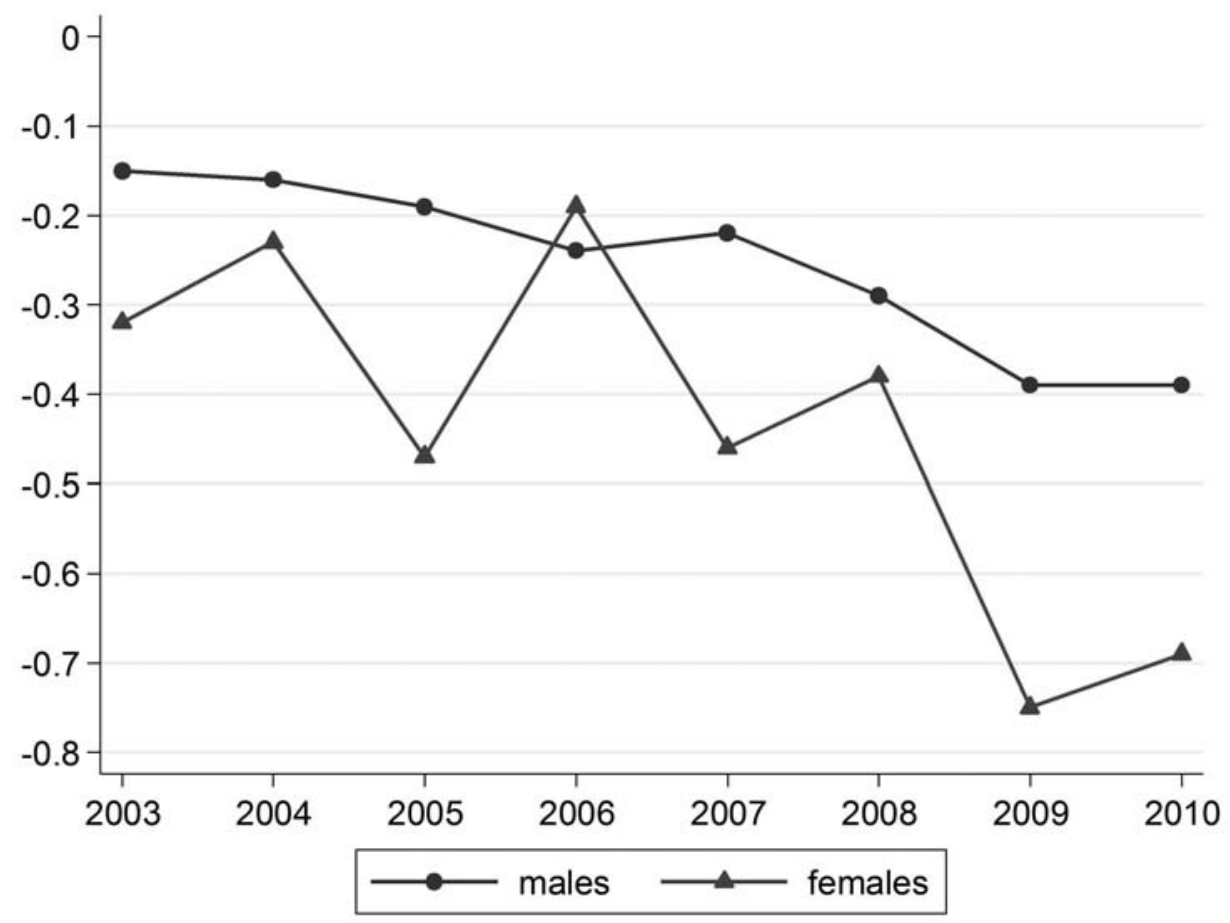

Figure 2. Correlation for those retiring above 54, with minimum 20 years of contribution, between 2003 and 2010

also reports a negative and time-decreasing correlation, only the values are less extreme.

Further delimiting the analysis, we only consider those who retired at or above the normal retirement age. Figure 3 still reports a negative correlation, but with low absolute values.

Note, that Granseth et al. (2016) repeated this calculation for Austria, Germany, and Sweden, and obtained partly similar, partly different results.

Now, we are moving from aggregate statistics to a somewhat disaggregated analysis. In a fair pension system, the benefits are smooth functions of the length of contribution and the retirement age. In contrast, we shall see that this is only partly fulfilled in the Hungarian system.

Tables 3 and 4 display the relative size and the relative benefit of those male and female groups whose members retired in 2011 on their own right, breaking down the data according to retirement age and length of contribution. (Confining attention to old-age pensioners would yield similar results.) To have perspicuous 


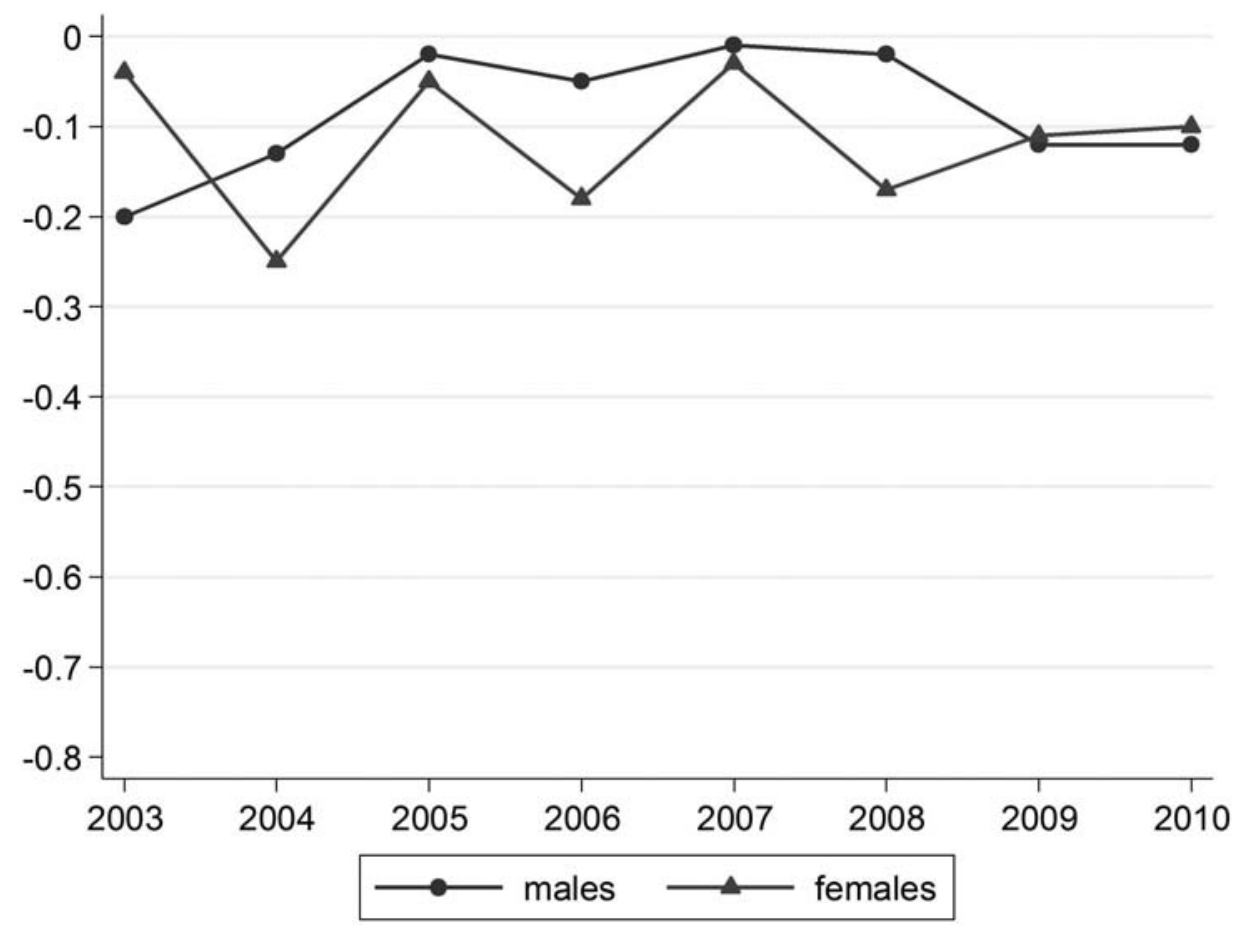

Figure 3. Correlation for those retiring at or above the normal retirement age, between 2003 and 2010

tables, we drop the categories with extreme lengths of contributions. Note that the ratio of the number of all new male retirees (55,100 in Table A3.6) to that of being in normal retirement age $(57,000$, Table $A 3.4)$ is about $97.4 \%$ and the relative benefit (with respect to the nationwide net wage, 144,100 HUF) is equal to $71 \%$, reaching its peak at the retirement age of 61 with $99 \%$.

The related numbers for females in Table 4 (using the absolute numbers from Table A3.7) are as follows: retirement ratio is equal to $135 \%$ and the relative benefit is equal to $66 \%$, reaching its peak at the retirement age of 60 with $86 \%$. 2011 was a singular year when the Females 40 was already introduced, but the permissive system of early retirement was still valid. Furthermore, the minimal retirement age of female cohort 1952 just rose from 57 to 59 . We call the Reader's attention to the bifurcation at the length of contribution of 40. For example, considering employees retiring at 60, those with length of contribution of 35-39 have a benefit of $56.7 \%$, while those with length of contribution of $40-44$ have a benefit of $105.9 \%$. 
Table 3. Relative size and benefits of male groups retired in 2011 - retirement age and length of contribution

\begin{tabular}{l|c|c|c|c|c|c}
\hline \multirow{2}{*}{ Age } & \multicolumn{2}{|c|}{ Size - Length of contribution } & \multicolumn{3}{c}{ Benefit - Length of contribution } \\
\cline { 2 - 7 } & $35-39$ & $40-44$ & $\begin{array}{c}\text { (Full sample) } \\
\text { Total }\end{array}$ & $35-39$ & $40-44$ & $\begin{array}{c}\text { (Full sample) } \\
\text { Average }\end{array}$ \\
\hline $54-55$ & 0.012 & 0.005 & $\mathbf{0 . 0 3 3}$ & 0.710 & 0.768 & $\mathbf{0 . 6 2 7}$ \\
\hline $56-57$ & 0.012 & 0.019 & $\mathbf{0 . 0 4 4}$ & 0.769 & 0.802 & $\mathbf{0 . 7 0 8}$ \\
\hline $58-59$ & 0.019 & 0.110 & $\mathbf{0 . 1 6 0}$ & 0.797 & 0.826 & $\mathbf{0 . 8 0 7}$ \\
\hline 60 & 0.047 & 0.239 & $\mathbf{0 . 3 7 8}$ & 0.555 & 0.753 & $\mathbf{0 . 7 3 2}$ \\
\hline 61 & 0.005 & 0.021 & $\mathbf{0 . 0 3 1}$ & 0.567 & 1.118 & $\mathbf{0 . 9 8 3}$ \\
\hline $62-63$ & 0.030 & 0.030 & $\mathbf{0 . 1 6 0}$ & 0.559 & 1.246 & $\mathbf{0 . 6 6 7}$ \\
\hline Total & $\mathbf{0 . 1 3 9}$ & $\mathbf{0 . 4 2 2}$ & $\mathbf{0 . 9 7 4}$ & $\mathbf{0 . 6 3 7}$ & $\mathbf{0 . 8 2 7}$ & $\mathbf{0 . 7 0 7}$ \\
\hline
\end{tabular}

Source: ONYF (2012, p. 109: Table 9.1).

Note: Relative benefit $=$ benefit $/$ nationwide net wage.

Table 4. Relative size and benefits of female groups retired in 2011

- retirement age and length of contribution

\begin{tabular}{l|c|c|c|c|c|c|c|c}
\hline \multirow{2}{*}{ Age } & \multicolumn{4}{|c|}{ Size - Length of contribution } & \multicolumn{4}{c}{ Benefit - Length of contribution } \\
\cline { 2 - 9 } & $30-34$ & $35-39$ & $40-44$ & Total & $30-34$ & $35-39$ & $40-44$ & Average \\
\hline $54-55$ & 0.004 & 0.010 & 0.091 & $\mathbf{0 . 1 1 5}$ & 0.515 & 0.606 & 0.638 & $\mathbf{0 . 6 1 2}$ \\
\hline $56-57$ & 0.003 & 0.013 & 0.336 & $\mathbf{0 . 3 5 7}$ & 0.476 & 0.623 & 0.681 & $\mathbf{0 . 6 7 2}$ \\
\hline $58-59$ & 0.006 & 0.089 & 0.498 & $\mathbf{0 . 5 9 9}$ & 0.455 & 0.576 & 0.783 & $\mathbf{0 . 7 4 7}$ \\
\hline 60 & 0.003 & 0.006 & 0.017 & $\mathbf{0 . 0 2 7}$ & 0.410 & 0.576 & 1.059 & $\mathbf{0 . 8 6 5}$ \\
\hline 61 & 0.001 & 0.001 & 0.003 & $\mathbf{0 . 0 0 6}$ & 0.415 & 0.555 & 1.108 & $\mathbf{0 . 7 3 9}$ \\
\hline $62-63$ & 0.027 & 0.006 & 0.003 & $\mathbf{0 . 1 1 3}$ & 0.441 & 0.530 & 1.103 & $\mathbf{0 . 4 7 5}$ \\
\hline Total & $\mathbf{0 . 0 6 5}$ & $\mathbf{0 . 1 3 1}$ & $\mathbf{0 . 9 4 9}$ & $\mathbf{1 . 3 4 7}$ & $\mathbf{0 . 4 8 6}$ & $\mathbf{0 . 5 8 1}$ & $\mathbf{0 . 7 3 9}$ & $\mathbf{0 . 6 6 1}$ \\
\hline
\end{tabular}

Source: ONYF (2012, p. 109: Table 9.2).

\section{EXCEPTIONAL/RIGID SYSTEM (HUNGARY FROM 2012)}

We shall put the present Hungarian system into a model framework and then display its impact in table form.

\subsection{Framework}

The analysis of the current (exceptional/rigid) Hungarian system is more important than the previous system (with exemptions). Since in the new system the distinction between females and males has reappeared, we should double all our equations correspondingly (generally omitted). The aggregated balance equations (4) and (5) would be obtained by the summation of the two variants. 
Equation (3) is replaced by the equation of the favoured females:

$$
b(R, S, w)=\gamma S T(w) \text { if } S \geq 40 \text { and } R<R^{*} .
$$

Equation (3) is modified into the equation below for all the others, retiring in the rigid system:

$$
b(R, S, w)=\left[1+\delta\left(R-R^{*}\right)\right] c_{S} T(w) \quad \text { if } R \geq R^{*} .
$$

There is a further complication: years spent in vocational schools and higher education before 1998 are counted in the formula but no in the condition of (8). A smaller, but similar problem arises with the years spent in raising a child below age 3. Currently (2017), the parameter values of the Hungarian system are as follows: $R^{*}=63.5$ years: $\delta=0.06$ and $\gamma=0.02, R_{\mathrm{m}}=R^{*}$, early retirement is only allowed for women, if $S \geq 40$, but without any deduction; minimum length of contribution: $S_{\mathrm{m}}=20$ years.

\subsection{Females 40}

Table 5 displays the data of the Females 40 programme as it stood in $2013^{7}$. The largest cohort is of 1955, its average retirement age is about 58 years, and its average length of contribution is about 41 years. The majority retired with 40 years of rights, but $15 \%$ and $11 \%$ with 42 and 43 years, respectively.

\begin{tabular}{|c|c|c|c|c|c|c|c|c|}
\hline \multirow[t]{2}{*}{$\begin{array}{l}\text { Birth } \\
\text { year }\end{array}$} & \multirow[t]{2}{*}{$\begin{array}{c}\text { Size } \\
\text { distri- } \\
\text { bution, \% }\end{array}$} & \multirow[t]{2}{*}{$\begin{array}{c}\text { Average } \\
\text { retirement } \\
\text { age }\end{array}$} & \multirow[t]{2}{*}{$\begin{array}{c}\text { Average } \\
\text { length of } \\
\text { employment }\end{array}$} & \multicolumn{5}{|c|}{$\begin{array}{c}\text { Size distribution according to contribution } \\
\text { length, } \\
\%\end{array}$} \\
\hline & & & & 40 & 41 & 42 & 43 & 44 \\
\hline 1953 & 4.9 & 60.0 & 41.5 & 37.7 & 29.4 & 18.4 & 4.9 & 5.1 \\
\hline 1954 & 26.6 & 59.0 & 41.1 & 59.7 & 16.1 & 8.5 & 8.5 & 4.4 \\
\hline 1955 & 32.9 & 58.2 & 41.1 & 61.4 & 9.3 & 15.2 & 10.5 & 1.7 \\
\hline 1956 & 17.7 & 57.1 & 41.7 & 31.2 & 17.4 & 37.8 & 11.3 & 0.0 \\
\hline 1957 & 9.3 & 56.1 & 40.7 & 65.6 & 23.6 & 7.2 & 0.0 & $*$ \\
\hline 1958 & 4.7 & 55.2 & 40.3 & 87.1 & 9.7 & $*$ & $*$ & $*$ \\
\hline Average & 100.0 & 57.9 & 41.1 & 56.3 & 14.8 & 15.9 & 8.2 & 2.0 \\
\hline
\end{tabular}

Table 5. Data of Females 40, 2013

Source: ONYF (2014, p. 111-112, Table 6.9)

For its details see Mihályi - Vincze 2016. 
Table 6 shows the relative benefits of the same categories. The original (uncensored) table also demonstrates that those newly retired who were born in 1951 $(0.3 \%)$ had an average net valorised wage of $118 \%$, while those born in 1952 $(1.3 \%)$ had only $103.5 \%$. Our censored table displays that those born in 1956 or later had still a lower average net valorised wage of $83.3 \%$.

Table 6. Relative benefits of Females 40, retiring in 2013, in terms of nationwide net wage

\begin{tabular}{|c|c|c|c|c|c|c|c|c|}
\hline \multirow[t]{2}{*}{$\begin{array}{l}\text { Birth } \\
\text { year }\end{array}$} & \multirow[t]{2}{*}{$\begin{array}{l}\text { Relative } \\
\text { average } \\
\text { earning }\end{array}$} & \multirow[t]{2}{*}{$\begin{array}{c}\text { Average } \\
\text { initial } \\
\text { benefit }\end{array}$} & \multirow[t]{2}{*}{$\begin{array}{l}\text { Average } \\
\text { length of } \\
\text { rights }\end{array}$} & \multicolumn{5}{|c|}{$\begin{array}{c}\text { Size distribution according to contribution } \\
\text { length, } \\
\%\end{array}$} \\
\hline & & & & 40 & 41 & 42 & 43 & 44 \\
\hline 1953 & 0.938 & 0.771 & 40.5 & 70.6 & 18.2 & 6.9 & 2.3 & 1.2 \\
\hline 1954 & 0.954 & 0.776 & 40.2 & 86.9 & 10.4 & 1.8 & 0.6 & 0.2 \\
\hline 1955 & 0.954 & 0.775 & 40.2 & 90.2 & 8.0 & 1.2 & 0.4 & 0.2 \\
\hline 1956 & 0.793 & 0.655 & 40.2 & 89.8 & 8.8 & 1.0 & 0.3 & 0.2 \\
\hline 1957 & 0.792 & 0.639 & 40.2 & 91.7 & 7.6 & 0.6 & 0.0 & $*$ \\
\hline 1958 & 0.760 & 0.609 & 40.1 & 95.0 & 5.0 & $*$ & $*$ & $*$ \\
\hline Average & 0.897 & 0.731 & 40.2 & 88.2 & 9.1 & 1.5 & 0.6 & 0.3 \\
\hline
\end{tabular}

Source: ONYF (2014, p. 111-112, Table 6.9) censored, and Table A3.3.

To make the tables shorter, we cut out the less important very early and very late birth years (-1952 and 1959+, respectively) and the similarly extremely short and long length of contributions ( -39 and $45+$, respectively): the displayed shares do not add up to 1 . Similarly, the averages refer to the whole population.

Judging fairness, in addition to the retirement age and the length of contribution, we have to take into account the remaining life expectancy. To widen the analysis, we cite a number of important data from 2012 about the dependence of life expectancy on the earning in Hungary from the path-breaking study of Molnár - Hollós Marosi (2015). Dropping the lowest decile of pensions (to avoid complications stemming from partial pensions received by emigrants), the foregoing paper divided the members of the remaining nine deciles into four equal parts. For example, for males, the lowest benefits were between 43.2 and $61.2 \%$ of average net earning, while their life expectancy at 60 was equal to 17.1 years. The highest benefits started at $104.3 \%$ and the respective life expectancy was four years longer. The female earnings were uniformly lower and the life expectancy hardly depended on the earning. ${ }^{8}$

8 The foregoing study presents interesting data on the dependence of life expectancy and the retirement age, too. Unfortunately, the categories are too large, therefore only slight differences arise. For example, in 2012, Hungarian males who retired before reaching age 59 had a 
One of the main issues of the present paper is as follows: what is the impact of the elimination of early retirement except for Females 40? Table 7 translates the model calculations of Table 1 to the exceptional/rigid system. Rows 4-6 are dropped, since they are identical to those of Table 1. Returning to our earlier examples: 0 benefit stands in cell $(60,38)$, while for females, cell $(58,40)$ jumps from $70.4 \%$ to $80 \%$ ! This is obviously unfair.

Table 7. Exceptional/rigid benefits - retirement ages and length of contribution (females)

\begin{tabular}{l|c|c|c|c|c}
\hline $\begin{array}{l}\text { Years of contribution, } S \\
\text { Retirement age, } R\end{array}$ & 36 & 38 & 40 & 42 & 44 \\
\hline 58 & 0 & 0 & 0.80 & 0.84 & 0.88 \\
\hline 60 & 0 & 0 & 0.80 & 0.84 & 0.88 \\
\hline
\end{tabular}

Note: In terms of net wage. Model calculations.

Now, it is time to present some data on real outcomes. First Table 8 displays the characteristics of males, females, and Females 40 between 2006 and 2014. The outcome is chaotic. The relative size of newly retired cohorts developed erratically. For example, in 2010 , the number of newly retired females $(13,600)$ was as low as $20 \%$ of the number of those females of normal retirement age $(68,800)$, while in 2011 , it jumped to $119 \%(84,900 / 71,100)$. In $2007,101 \%$ of males of the cohort size retired $(50,900 / 50,300)$, while in 2008 , only $54 \%(25,700 / 47,400)$. Of course, everything can be explained by the erratic developments of the two groups of rules (benefit-wage schedule and retirement rules). Or, to give another example, in 2010, females delayed their retirement until the much more favourable era starting in 2011. In 2007, males (and females) surpassed the sudden decrease of $8 \%$ in the initial pensions announced for 2008, in 2014, the normal retirement age rose by $1 / 2$ year.

\subsection{Detailed observations}

Using the so-called Attached Administrative Data Base of the Hungarian Academy of Sciences, ${ }^{9}$ we can obtain a finer picture on the situation of the newly retired females between 2002 and 2011. Taking into account our topic, we shall

remaining life expectancy of 14.9 years, while those retiring older than 61, had another 16.1 years. (The corresponding demographic numbers are 16.7 and 15.4 years, respectively.) For females, those retiring between 50 and 54 years had another 22.5 years, while those retiring beyond 61 years, live only slightly longer: 23.1 years. (Note that the unofficial data of Esö et al. 2011, Tables A1-A2, cited much larger differences for those who died in 2004.)

9 Access to these data can be required from the Data Bank, e-mail address: adatbank@mta.hu 
Table 8. Retirement ages and relative sizes: males, females and Females 40

\begin{tabular}{l|c|c|c|c|c|c}
\hline \multirow{2}{*}{ Year } & \multicolumn{2}{|c|}{ Males } & \multicolumn{2}{c|}{ Females } & \multicolumn{2}{c}{ Females 40 } \\
\cline { 2 - 7 } & $\begin{array}{c}\text { Average } \\
\text { retirement } \\
\text { age (year) }\end{array}$ & $\begin{array}{c}\text { Relative } \\
\text { size }\end{array}$ & $\begin{array}{c}\text { Average } \\
\text { retirement } \\
\text { age (year) }\end{array}$ & $\begin{array}{c}\text { Relative } \\
\text { size }\end{array}$ & $\begin{array}{c}\text { Average } \\
\text { retirement } \\
\text { age (year) }\end{array}$ & Relative size \\
\hline 2006 & 59.9 & 0.638 & 57.5 & 0.758 & & \\
\hline 2007 & 59.7 & 1.012 & 57.8 & 1.028 & & \\
\hline 2008 & 59.8 & 0.542 & 57.3 & 0.611 & & \\
\hline 2009 & 59.7 & 0.727 & 59.9 & 0.239 & & \\
\hline 2010 & 60.2 & 0.676 & 60.7 & 0.198 & & $0.769^{*}$ \\
\hline 2011 & 60.3 & 0.753 & 58.5 & 1.194 & 57.6 & 0.374 \\
\hline 2012 & 62.0 & 0.365 & 59.1 & 0.727 & 57.8 & 0.329 \\
\hline 2013 & 62.2 & 0.356 & 59.5 & 0.544 & 57.8 & 0.360 \\
\hline 2014 & 62.2 & 0.249 & 59.3 & 0.484 & 58.2 & \\
\hline
\end{tabular}

Source: Fazekas - Varga (2015, p. 262, Table 11.5) and Tables A3.4 and A3.5.

Note: * The number for Females 40 in 2011 also contains those who retired earlier, but were reclassified in 2011.

Table 9. Female pensioners of 2011: average last earning and initial benefit

\begin{tabular}{l|c|c|c|c}
\hline Type of retirement & $\begin{array}{c}\text { Relative } \\
\text { average benefit }\end{array}$ & Share, \% & $\begin{array}{c}\text { Relative average } \\
\text { earning } \\
3 \text { months } \\
\text { before retirement }\end{array}$ & $\begin{array}{c}\text { Share of employed } \\
3 \text { months } \\
\text { before retirement }\end{array}$ \\
\hline Females 40 (54-59) & 0.772 & 43.5 & 1.289 & 39.7 \\
\hline Early pensioners & 0.822 & 17.8 & 1.565 & 10.3 \\
\hline $\begin{array}{l}\text { Females retiring } \\
\text { at the normal } \\
\text { retirement age }\end{array}$ & 0.432 & 6.1 & 0.802 & 1.3 \\
\hline
\end{tabular}

Note: In terms of nationwide net wage. Administrative data.

distinguish three types of old-age retirement: early retirement, Females 40 and "normal" retirement (ironically referring to the rare retirement at NRA). We shall compare now the three groups (with respect to fragmentation of career, earning before retirement, and the initial pension).

A lot of Hungarian statistics attest that the share of early retirees was high; moreover, normal retirement has been an exception rather than the rule. The changes in the average retirement age only follow the changes in the law. Already commenting on Table 6, we called the Reader's attention to the critical role of the length of contribution of 40 , and to the inequalities in benefits (present between those who retire with 35-39 and 40-44 years of contribution, respectively). 
Applying our administrative data, we were unable to take into account the length of contribution, but we relied on the initial pensions and the earnings before retirement. According to Table 9, the participants in Females 40 had as benefits $77.2 \%$ of the average net wage, somewhat lagged behind those of early retirees $(82.2 \%)$, but surpassed by far those of the "normal" retirees $(43.2 \%)$.

Table 10 breaks down the category of those pensioners who retired in the first year of starting Females 40 into three age-groups. With the rise of the retirement age, not only the relative benefits, but also the relative value of pre-retirement net wage with respect to the nationwide net wage grew steeply: 76.5\% (aged 54-56) vs. $94.8 \%$ (aged 58-59).

Table 10. The pension and pre-retirement date of Females 40 in three age-groups, 2011

\begin{tabular}{l|c|c|c|c}
\hline Retirement age & $\begin{array}{c}\text { Relative } \\
\text { average } \\
\text { benefit }\end{array}$ & Relative size & $\begin{array}{c}\text { Ratio of gross } \\
\text { wage to the average one }\end{array}$ & $\begin{array}{c}\text { The relative size of the } \\
\text { workers groups 3 months } \\
\text { before retirement }\end{array}$ \\
\hline $54-56$ & 0.701 & 0.184 & 0.765 & 0.173 \\
\hline 57 & 0.744 & 0.163 & 0.802 & 0.149 \\
\hline $58-59$ & 0.836 & 0.260 & 0.948 & 0.236 \\
\hline
\end{tabular}

Note: In terms of nationwide net wage. Administrative data.

Looking at Figure 4 (obtained by the so-called Combined Administrative Database $^{10}$ ), it is evident that the earlier (i.e. at the younger age) one benefited from Females 40, the lower her benefit and last earning. Comparing the beneficiaries of Females 40 with non-retired workers of the same age, we find the following difference: until age 57, the latter earn more than the former, but at age 58, the situation is reversed. Knowing this tipping point, the birth-cohort dependence of pension and earnings depicted in Table 5 becomes clear. We also note that those who retired at the normal retirement age are now in an even worse situation.

Table 11 summarises the data of all females retired in the period 2012-2014. We emphasise that in all the three years, the number of those retiring in Females 40 was 1.5-3 times higher than those at or above the normal retirement age; they were 4-5 years younger and the difference between the contribution lengths of the two categories dropped from 14 to 11 years. Through the zigzagged accrual schedule (presented in Table 2 above), the loss of the second category was somewhat lower than suggested by Tables 1 and 7 , it remains severe.

10 This database was created by the combination of five administrative organisations' data. It contains the labour force data of $50 \%$ of the Hungarian population between 15 and 74 years, in a monthly breakdown for the period 2003-2011. To make our calculations, in addition to labour force and transfer data, we analysed the NYUFIG data. We have created a detached database, which contains the benefit decision and payment, furthermore, it unifies the benefit amount on an annual base. 


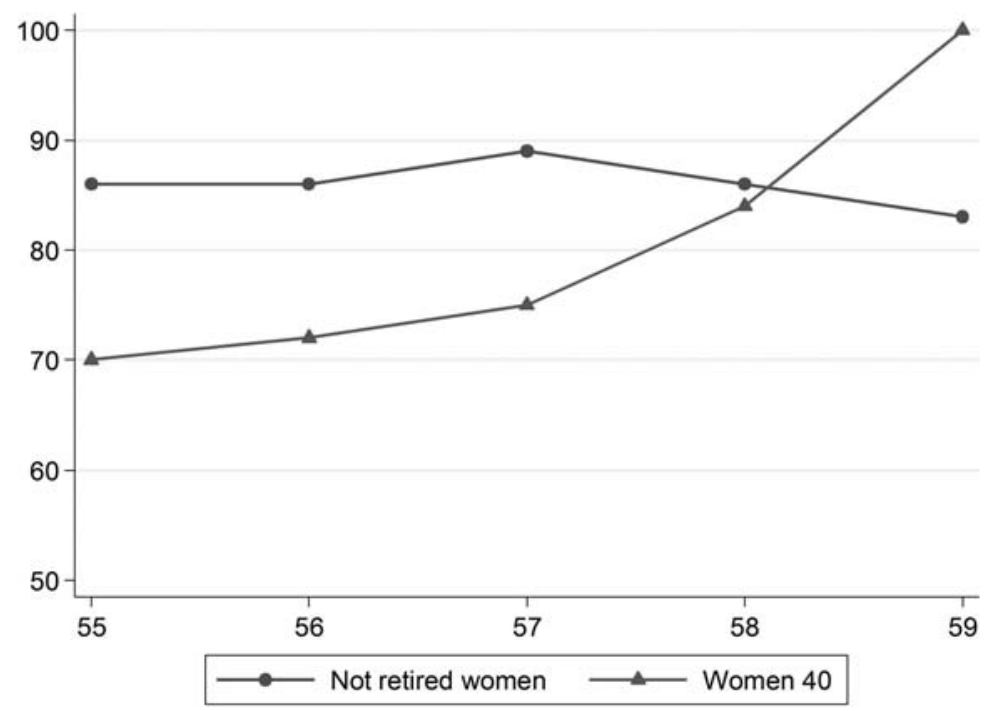

Figure 4. Monthly average wages in May 2010 at an annual percentage of the average wage in 2010

Table 11. The most important characteristics of female retirees, 2012-2014

\begin{tabular}{l|l|c|c|c|c}
\hline Year & \multicolumn{1}{|c|}{ Type } & Size & $\begin{array}{c}\text { Average } \\
\text { age (year) }\end{array}$ & $\begin{array}{c}\text { Average length of } \\
\text { contribution (year) }\end{array}$ & $\begin{array}{c}\text { Average } \\
\text { relative benefits }\end{array}$ \\
\hline \multirow{2}{2}{012} & $\begin{array}{l}\text { Reaching } \\
\text { NRA }\end{array}$ & 0.144 & 62.6 & 26.0 & 0.450 \\
\cline { 2 - 6 } & Females 40 & 0.389 & 57.8 & 40.7 & 0.772 \\
\hline \multirow{2}{*}{2013} & $\begin{array}{l}\text { Reaching } \\
\text { NRA }\end{array}$ & 0.195 & 62.3 & 28.1 & 0.485 \\
\cline { 2 - 6 } & Females 40 & 0.324 & 58.0 & 40.7 & 0.731 \\
\hline & $\begin{array}{l}\text { Reaching } \\
\text { NRA }\end{array}$ & 0.130 & 62.8 & 30.2 & 0.522 \\
\cline { 2 - 6 } & Females 40 & 0.374 & 58.3 & 40.9 & 0.742 \\
\hline
\end{tabular}

Source: ONYF (2016, p. 51-53, Table 4.1).

Note: In terms of nationwide net wage. 


\section{CONCLUSIONS}

It is almost a commonplace that in a fair system - in addition to the average lifetime earning and within wide limits - the initial benefit is a strongly increasing function of the length of contribution and of the retirement age. Considering the pension contribution as forced saving, in the resulting life annuity both the lengths of saving and of dissaving periods are important. This principle is followed in most countries, but not in Hungary: either the contribution length or the retirement age has been decisive. Before 2010, every man or woman with sufficiently long contribution was allowed to retire with full benefit. Since 2011, having accumulated 40 years of rights, every woman can retire without any deduction. On the other hand, except for Females 40, nobody can retire before reaching the normal retirement age. For example, in 2016, even 39 years of right did not allow a 62 year-old woman to retire, even "paying" serious deduction.

Both the official statistics and our special purpose data set reveal the significant distortion implied by the neglect of either the retirement age or the length of contribution in the calculation of benefits. The data presented underline the surprising fact that in the Hungarian system with exemption, there was a strong negative correlation between these two variables. The later one retired, the shorter was his/her contribution period. This was only possible because a large part of the workers - frequently unintended - worked with long breaks. We conjecture that this negative correlation survived after 2011, but we cannot document it.

The beneficiaries of Females 40 form a strongly heterogeneous group. Breaking down the group by age (and the underlying education level), one can distinguish two subgroups: one is disadvantaged (aged 54-56) and another is advantaged (aged 58-59), the latter's members resemble the early retirees. Since 2016, most women with a university diploma have the 40-year at the age 63 and then the rigid prohibition of early retirement does not affect them.

Using the data of the Central Statistical Office and the Central Administration of National Pension Insurance, we also analysed the post 2010 situation. We emphasised that Females 40 gives a significant advantage to a lot of women and causes also significant and unfair losses to others. The elimination of early male retirement has already produced strong tensions and due to further significant rise in the normal retirement age, it will become unbearable. In addition, the special favour does not apply to those females whose careers are fragmented and at the same time, their average net earning is below those of the beneficiaries.

The new and ad hoc Females 40+ (promulgated in January 2016) tries to mitigate this problem in an awkward way: for several months, the government is ready to pay the full compensation of those unemployed and previously low-paid females to accumulate 40 years of rights, who deserve help - even by the govern- 
ment's evaluation. The fair solution is so obvious: actuarial reduction of benefits at early retirement!

It would be socially optimal to close down Females 40 and introduce flexible retirement (successfully applied in most developed countries), which are satisfactory to the employees and the government. The longer the Hungarian government insists on the exceptional/rigid system, the stronger the tensions that will be accumulated. In our opinion, even having introduced a flexible system, following a rigid social norm, a lot of workers would still retire as early as possible, even if they received reduced pensions. At the same time, we hope that with carefully designed parameter values, the foregoing tendency can be limited and a socially optimal system can be created which provides room for individual choice within certain limits and is at the same time sustainable.

\section{REFERENCES}

Augusztinovics, M. - Gál, R. I. - Matits, Á. - Máté, L. - Simonovits, A. - Stahl, J. (2002): The Hungarian Pension System before and after the 1998 Reform. In: Fultz, E. (ed.): Pension Reform in Central and Eastern Europe, Vol. 1-2, Geneva: International Labour Office.

Augusztinovics, M. - Köllő, J. (2008): Pension System and Fragmented Labor Market Careers. In: Gál, R. I. - Iwasaki, I. - Széman, Zs. (eds): Assessing Intergenerational Equity: An Interdisciplinary Study of Aging and Pension Reform in Hungary. Budapest: Akadémiai Kiadó, pp. 154-170.

Augusztinovics, M. - Köllö, J. (2009): Decreased Employment and Pensions. The Case of Hungary. In: Holzmann, R. - MacKellar, L. - Repansek, J. (eds): Pension Reform in Southeastern Europe. Linking to Labor and Financial Market Reform. Washington, D.C.: World Bank, pp. 89-104.

Bajkó, A. - Maknics, A. - Tóth, K. - Vékás, P. (2015): A magyar nyugdíjrendszer fenntarthatóságáról (On the Sustainability of the Hungarian Pension System). Közgazdasági Szemle, LXII (December): 1229-1257.

Chan, S. - Stevens, A. H. (2004): How does Job Loss Affect the Timing of Retirement? The B.E. Journal of Economic Analysis and Policy, 3(1): 1-26.

Cseres-Gergely, Zs. (2008): Incentive Effects in the Pension System of Hungary. In: Fazekas, K. - Cseres-Gergely, Zs. - Scharle, Á. (eds): The Hungarian Labor Market, Review and Analysis. Budapest: Institute of Economics, Research Center for Economics and Regional Sciences, Hungarian Academy of Sciences, pp. 103-115.

Diamond, P. A. (2003): Taxation, Incomplete Markets and Social Security, Munich Lectures. Cambridge, MA: MIT Press.

Eső, P. - Simonovits, A. (2002): Designing Optimal Benefits for Retirement. Northwestern University (IL) Discussion Papers, No. 1353.

Eső, P. - Simonovits A. - Tóth, J. (2011): Designing Benefit Rules for Flexible Retirement: Welfare and Redistribution. Acta Oeconomica, 61(1): 3-32.

Etgeton, S. (2016): Labor Market Frictions, Retirement and Inequality. Presentation at EEA-ESEM 2016 Conference, Geneva, 22-26 August. 
Fazekas, K. - Varga, J. (eds) (2015): The Hungarian Labor Market 2015. Budapest: Insitute of Economics, Research Center for Economics and Regional Sciences, Hungarian Academy of Sciences.

Freudenberg, Ch. - Berki, T. - Reiff, Á. (2016): A Long-Term Evaluation of Recent Hungarian Reforms. Magyar Nemzeti Bank Working Paper, No. WP 2.

Granseth, E. - Keck, W. - Nagl, W. - Simonovits - Tir, M. (2016): Negative Correlation between Retirement Age and Contribution Length? Budapest: Insitute of Economics, Research Center for Economics and Regional Sciences, Hungarian Academy of Sciences, Working Paper, No. 33.

Gustman, A. L. - Steinmeier, T. L. (1986): A Structural Retirement Model. Econometrica, 54(3): 555-584.

Krémer, B. (2013): Miért is olyan félelmetes a társadalmak számára az, ha az emberek tovább élnek? (Why Is It so Frightening if People Live Longer?) Szociológiai Szemle, 23(3): 51-83.

Manoli, D. - Weber, A. (2016): The Effect of the Early Retirement Age on Retirement Decisions. IZA Discussion Paper, No. 10154.

Mihályi, P. - Vincze, L. (2016): The Financial Consequences of the "Women and Men 40" Pension Scheme Concept. Economy and Finance, 3(1): 3-24.

Molnár, D. L. - Hollós Marosi, J. (2015): Az öregségi nyugdíjasok halandósága (The Mortality of Old-Age Retirees). Közgazdasági Szemle, LXII: 1258-1290.

Munnell, A. H. - Sanzenbacher, G. T. - Webb, A. A. - Gillis, Ch. M. (2016): Are Early Claimers Making a Mistake? Boston College, Center for Retirement Research, Working Paper, No. 5.

ONYF (2012): ONYF Statistical Yearbook, 2011 (in Hungarian). Budapest: Central Administration of National Pension Insurance (CANPI).

ONYF (2013): ONYF Statistical Yearbook, 2012 (in Hungarian). Budapest: CANPI.

ONYF (2014): ONYF Statistical Yearbook, 2013 (in Hungarian). Budapest: CANPI.

Rust, J. - Phelan, C. (1997): How Social Security and Medicare Affect Retirement Behavior in a World of Incomplete Markets. Econometrica, 65(4): 781-831.

Simonovits, A. (2008): The Pay-as-You-Go System and the Permanent Reform: The First Pillar. In: Gál, R. I. - Iwasaki, I. - Széman, Zs. (eds): Assessing Intergenerational Equity. Budapest, Akadémiai Kiadó, pp. 71-86.

Simonovits, A. (2016): Intra- and Intergenerational Transfers: Simple Paternalistic Models. Manuscript.

Stock, J. H. - Wise, D. A. (1990): Pensions, the Option Value of Work and Retirement. Econometrica, 58(5): 1151-1180. 


\section{APPENDICES}

\section{APPENDIX 1. WELFARE COMPARISON OF DIFFERENT MECHANISMS AND PARTIAL RETIREMENT}

(i) In the main text, the gainers and the losers were defined without relying on lifetime utility functions. Only direct comparisons were made: the gainers are those who obtain higher benefits or have lower net balances in the alternative mechanism than in the flexible one. In contrast, Appendix 1 outlines the basics of welfare comparison. Let $i=1,2, \ldots, n$ be the index of various types, $f_{i}$ be the share in the population, and $\mathrm{M}$ be the alternative system (e.g. linear flexible, exceptional, rigid). Let $U_{i}\left(R_{i}, S_{\vec{l}}, b_{i}\right)$ be the lifetime utility of type $i$, and $V$ be the utilitarian social welfare function:

$$
V=\sum_{i} f_{i} U_{i}\left(R_{i}, S_{i}, b_{i}\right)
$$

To compare two mechanisms $M_{1}$ and $M_{2}$, we define $M_{1}$ is better than $M_{2}$ if the first provides higher welfare than the second. Formally:

$$
V\left(\mathrm{M}_{1}\right)>V\left(\mathrm{M}_{2}\right) \text {. }
$$

We conjecture in general and show numerically in particular in Appendix 2 below that in a well-calibrated model, the flexible mechanism typically provides higher welfare than either that with exemption or the rigid; therefore the former is better than the latter.

(ii) International experts have known for a long period that even the so-called flexible (variable) retirement system is not flexible enough, at least with respect to the system of partial retirement. Though the international experiences are not yet encouraging (even in the Swedish system?), we hope that it is not the idea but only the practice that is bad. Here we give its formal description. There are two retirement ages: $R_{1}$ and $R_{2}$, those of the partial with weight $\alpha$ and of the full retirement, and two rather than one length of contribution: $S_{1}$ and $S_{2}$. The net lifetime balance is given as

(1') $d\left(R_{1}, R_{2}, S_{1}, S_{2}, w\right)=\tau w\left[S_{1}+(1-\alpha) S_{2}\right]-\left[\alpha e_{R 12}+e_{R 2}\right] b\left(R_{1}, R_{2}, S_{1}, S_{2}, T(w)\right)$,

$e_{R 12}$ being the number of expected years spent in interval $\left[R_{1}, R_{2}\right)$. Of course, if $R_{1}$ $=R_{2}$ or $\alpha=1$, then the partial retirement reduces to the flexible one. For $d=0$, the traditional NDC is obtained. 


\section{APPENDIX 2. THE IMPACT OF THE RETIREMENT RULES ON THE CORRELATION AND WELFARE}

In this Appendix, a simple model is constructed, where the impact of the retirement rules on the correlation coefficient and welfare (numerically represented by relative efficiency) can be studied theoretically. We shall show that typically as we move smoothly from the exceptional/rigid retirement rules to the flexible retirement, the foregoing correlation grows from -1 to 1 and the welfare rises.

\section{Theory}

The starting point is that there are groups in the population whose average fragmentation rates are different. Let integer $n>1$ be the number of groups, $k=1$, $2, \ldots, n$ be the generic group index. Let $L$ be the common age when people start working (possibly including the years spent in higher education) and $D$ be the common age when they die. Denote $R_{k}$ and $S_{k}$ the retirement age and the years of contribution, respectively, and $1-\varphi_{k}$ be the degree of fragmentation of type $k$ 's career. Then by definition, $S_{k}=\varphi_{k}\left(R_{k}-L\right)$. We shall index the groups in an increasing order of fragmentation: $\varphi_{k}>\varphi_{k+1}>0$, and $\varphi_{1}=1$ (nonfragmented career). Let $f_{k}(>0)$ be the population share of group $k$ with $\sum_{k} f_{k}=1$.

To avoid confusion between the individual-based approach in Section 2 and the category-based approach here, we repeat some definition from Section 2. We need the expected retirement age and the expected years of contribution, respectively:

and their variances:

$$
\mathbf{E} R=\sum_{k} f_{k} R_{k} \text { and } \mathbf{E} S=\sum_{k} f_{k} S_{k}
$$

$$
\mathbf{D}^{2} R=\mathbf{E}(R-\mathbf{E} R)^{2} \text { and } \mathbf{D}^{2} S=\mathbf{E}(S-\mathbf{E} S)^{2} .
$$

Finally we define the correlation coefficient between $R$ and $S$ :

$$
\rho(R, S)=\mathbf{E}((R-\mathbf{E} R)(S-\mathbf{E} S)) /(\mathbf{D} R \mathbf{D} S) \text { if } \mathbf{D} R>0 \text { and } \mathbf{D} S>0 .
$$

As is known, $-1 \leq \rho(R, S) \leq 1$, and the equalities hold if and only if $S=A R+B$, with $A<0$ and $A>0$, respectively. (Note that if all the degrees of fragmentation were close to each other, then $\rho(R, S) \approx 1$ but this is not the case.)

The simplest way to model a family of the retirement rules is the following. There is a normal retirement age $\left(R^{*}\right)$ and there are two critical values: a critical length of contribution $\left(S_{\mathrm{o}}\right)$ and a critical retirement age $\left(R_{\mathrm{o}}\right)$. To make the model meaningful, it is assumed that type 1 (with full employment) has at least the critical length of contribution if (s)he retires at the normal retirement age: $S_{\mathrm{o}} \leq$ 
$R^{*}-L_{1}$. It is also assumed that the critical retirement age is at most as high as the normal: $R_{\mathrm{o}} \leq R^{*}$.

In case of a sufficiently long contribution, the benefit is proportional to the years of contribution and the net wage $1-\tau$, where $\tau$ is the contribution rate and $\gamma$ is the proportionality factor (the accrual rate):

$$
b(R, S)=\gamma S(1-\tau) \text { if } S \geq S_{\mathrm{o}} .
$$

In case of sufficiently late retirement, but still below the normal retirement age and shorter than critical length of contribution (but at least as long as the minimal length $S_{\mathrm{m}}$ ), the worker can retire with an annual deduction $\delta_{1}$ :

$$
b(R, S)=\gamma S(1-\tau)\left[1+\delta_{1}\left(R-R^{*}\right)\right] \text { if } R_{\mathrm{o}} \leq R \leq R^{*} \text { and } S_{\mathrm{m}} \leq S<S_{\mathrm{o}} .
$$

After reaching the normal retirement age, the second rule gives credit rather than deduction:

$$
b(R, S)=\gamma S(1-\tau)\left[1+\delta_{2}\left(R-R^{*}\right)\right] \text { if } R \geq R^{*} \text { and } S \geq S_{\mathrm{m}} .
$$

Otherwise no retirement is allowed. For simplicity, we introduce the notation

$$
b_{k}\left[R_{k}\right]=b\left(R_{k}, \varphi_{k}\left(R_{k}-L_{k}\right)\right) .
$$

Note, that our scheme contains the two extreme systems: (i) the exceptional/ rigid with $R_{\mathrm{o}}=R^{*}$ and $S_{\mathrm{o}}<R^{*}-L$ and (ii) flexible with $R_{\mathrm{o}}<R^{*}$ and $S_{\mathrm{o}}=R^{*}-L_{1}$.

To derive the retirement ages as a function of the retirement rules, we posit a standard lifetime utility function. It consists of three terms: the utility enjoyed while (i) working, (ii) being idle, and (iii) being retired:

$U\left[R_{k}\right]=[\log (1-\tau)-\varepsilon] \varphi_{k}\left(R_{k}-L\right)+[\log C-\varepsilon]\left(1-\varphi_{k}\right)\left(R_{k}-L_{k}\right)+\log b_{k}\left[R_{k}\right]\left(D-R_{k}\right)$, where $\varepsilon$ is the per-period utility loss due to work or unemployment and $C$ is the value of social income.

Finally, we define the per worker balance of the system, i.e. the difference between contributions and benefits:

$$
B=\tau \mathbf{E} S-C(\mathbf{E} R-\mathbf{E} S-L)-\mathbf{E}[b[R](D-R)] .
$$

\section{Numerical calculation}

Turning to numbers, we choose three types: $n=3$ and Table A2. 1 shows the three types' parameter values. 
Table A2.1. Parameters of the three types, normal case

\begin{tabular}{l|c|c|c}
\hline Types & 1 & 2 & 3 \\
\hline Shares $f_{k}$ & 0.6 & 0.3 & 0.1 \\
\hline Nonfragmentation $\varphi_{k}$ & 1.0 & 0.9 & 0.8 \\
\hline Disutility $\varepsilon_{k}$ & 1.0 & 1.3 & 1.7 \\
\hline
\end{tabular}

Note: Model calculations.

Other parameter values are as follows: $L=20, R^{*}=62, D=77, C=0.25$. For $\gamma$ $=0.03$, the balanced value of $c$ varies around 0.358 . The exceptional/rigid system is characterised by $S_{\mathrm{o}}=40$ and $R_{\mathrm{o}}=62$ and the flexible one by $S_{\mathrm{o}}=42, R_{\mathrm{o}}=60$ and $\delta_{1}=0.06$. We can achieve a smooth transition between the two extreme systems with the following equations:

$$
S_{\mathrm{o}}=40+0.5 x, R_{\mathrm{o}}=62-0.5 x \text { and } \delta_{1}=0.015 x, x=0,1,2,3,4 .
$$

To avoid the numerical ambiguity of the social welfare functions, we introduce the concept of relative efficiency. Mechanism $y$ 's relative efficiency with respect to that of $x$ is a positive real number $\omega$ if multiplying the wages and benefits by $\omega$ in $x$ yields the same welfare as the original $\mathrm{y}$. In formula:

$$
V[y]=V[x]+(D-L) \log \omega \text {, i.e. } \omega=\exp \{(V y]-V[x]) /(D-L)\} .
$$

Table A2.2 shows the results. As we claimed in the Introduction, during a smooth transition from the exceptional/rigid system to the flexible one, the correlation coefficient grows from -1 to 1 and the relative efficiency grows from 1 to 1.011 .

\begin{tabular}{|c|c|c|c|c|c|c|c|}
\hline \multirow{2}{*}{$\begin{array}{l}\text { Annual } \\
\text { deduction } \\
\delta_{1}\end{array}$} & \multicolumn{2}{|c|}{ Critical } & \multicolumn{3}{|c|}{ Retirement age for type } & \multirow{2}{*}{$\begin{array}{c}\text { Correla- } \\
\text { tion coeff. } \\
\rho(R, S)\end{array}$} & \multirow{2}{*}{$\begin{array}{c}\text { Relative } \\
\text { efficiency } \\
\omega\end{array}$} \\
\hline & $\begin{array}{l}\text { length of } \\
\text { employ- } \\
\text { ment, } S_{\text {o }}\end{array}$ & $\begin{array}{c}\text { retire- } \\
\text { ment } \\
\text { age, } R_{\mathrm{o}}\end{array}$ & $\begin{array}{c}1 \\
R_{1}\end{array}$ & $\begin{array}{l}2 \\
R_{2}\end{array}$ & $\begin{array}{c}3 \\
R_{3}\end{array}$ & & \\
\hline 0.000 & 40.0 & 62.0 & 60.1 & 62.0 & 62.0 & -0.875 & 1.000 \\
\hline 0.015 & 40.5 & 61.5 & 60.6 & 61.5 & 61.5 & -0.895 & 1.004 \\
\hline 0.030 & 41.0 & 61.0 & 61.0 & 61.0 & 61.0 & 0.001 & 1.008 \\
\hline 0.045 & 41.5 & 60.5 & 60.9 & 60.5 & 60.5 & 0.914 & 1.007 \\
\hline 0.060 & 42.0 & 60.0 & 62.0 & 60.4 & 60.0 & 1.000 & 1.011 \\
\hline
\end{tabular}

Table A2.2. Transition from the exceptional/rigid system to the flexible one, normal case

Note: Model calculations.

In sum, we considered career types with various degrees of fragmentation, when the system operates with a critical length of contribution and a critical retirement age plus an adjustment rate. As we raise the critical length and the de- 
duction rate, while diminish the critical age, we move from the exceptional/rigid system toward the flexible system, and the signed correlation coefficient between the length and age increases from -1 to 1 . This signals the improvement of fairness as well.

\section{A counter-example}

To show a case where the exceptional/rigid system is more efficient than the flexible one is, we choose parameter values where there is no fragmentation, the labour disutilities 1 and 3 change places, and the start and exit ages steeply rise with the lifespan.

Table A2.3. Parameters of the three types, counter-example

\begin{tabular}{l|c|c|c}
\hline Types & 1 & 2 & 3 \\
\hline Shares $f_{k}$ & 0.6 & 0.3 & 0.1 \\
\hline Disutility $\varepsilon_{k}$ & 1.0 & 1.3 & 1.7 \\
\hline Start working $L_{k}$ & 16.0 & 20.0 & 22.0 \\
\hline Age at death $D_{k}$ & 70.0 & 75.0 & 80.0 \\
\hline
\end{tabular}

Note: Model calculations.

Now the outcome of Table A2.4 is totally different from that of Table A2.2. The short-lived worker with heavy labour disutility can take early retirement, while the long-lived worker with light burden cannot. The correlation coefficient remains strongly negative, while the relative efficiency first stagnates then it diminishes.

Table A2.4. Transition from the exceptional/rigid system to the flexible one, counter-example

\begin{tabular}{|c|c|c|c|c|c|c|c|}
\hline \multirow{2}{*}{$\begin{array}{l}\text { Annual } \\
\text { deduction } \\
\delta\end{array}$} & \multicolumn{2}{|c|}{ Critical } & \multicolumn{3}{|c|}{ Retirement age for type } & \multirow{2}{*}{$\begin{array}{c}\text { Correla- } \\
\text { tion coeff. } \\
\rho(R, S)\end{array}$} & \multirow{2}{*}{$\begin{array}{c}\text { Relative } \\
\text { efficiency } \\
\omega\end{array}$} \\
\hline & $\begin{array}{l}\text { length of } \\
\text { employ- } \\
\text { ment, } S_{0}\end{array}$ & $\begin{array}{l}\text { retirement } \\
\text { age, } R_{\mathrm{o}}\end{array}$ & $\begin{array}{c}1 \\
R_{1}\end{array}$ & $\begin{array}{l}2 \\
R_{2}\end{array}$ & $\begin{array}{l}3 \\
R_{3}\end{array}$ & & \\
\hline 0.000 & 40.0 & 62.0 & 57.0 & 62.0 & 62.0 & -0.877 & 1.000 \\
\hline 0.015 & 40.5 & 61.5 & 57.0 & 61.5 & 61.5 & -0.886 & 1.000 \\
\hline 0.030 & 41.0 & 61.0 & 57.0 & 61.0 & 61.4 & -0.921 & 1.001 \\
\hline 0.045 & 41.5 & 60.5 & 57.6 & 60.5 & 62.0 & -0.990 & 0.999 \\
\hline 0.060 & 42.0 & 60.0 & 58.1 & 60.4 & 62.0 & -1.000 & 0.997 \\
\hline
\end{tabular}

Note: Model calculations. 


\section{APPENDIX 3. HUNGARIAN LABOUR AND PENSION STATISTICS}

Appendix 3 contains some basic statistics used in converting absolute Hungarian data into relative ones. We start the description with the basic parameter values of the Hungarian pension system. We only display the new parameter values. The meaning of the columns except for the last is straightforward: for example, the first row shows that in 2005, the male/female normal retirement ages were 62/60, the earliest ages were 57/60, and the minimal length of contribution for full benefit was $40 / 37$ years. The last column contains only two symbols: $V$ for varies with respect to age, length of contribution, and the calendar year. The second symbol -/0 means that there is no early retirement except for Females 40.

Table A3.1. Rising normal and earliest retirement ages and exceptions

\begin{tabular}{|c|c|c|c|c|}
\hline Year & $\begin{array}{c}\text { Normal retirement } \\
\text { age }(\mathrm{m} / \mathrm{f})\end{array}$ & $\begin{array}{c}\text { Earliest } \\
\text { retirement } \\
\text { age }(\mathrm{m} / \mathrm{f})\end{array}$ & $\begin{array}{l}\text { Minimal length of } \\
\text { contribution for full } \\
\text { benefit }(\mathrm{m} / \mathrm{f})\end{array}$ & $\begin{array}{c}\text { Annual deduction } \\
\text { rate }\end{array}$ \\
\hline 2005 & $62 / 60$ & $57 / 60$ & $40 / 37$ & $\mathrm{~V}$ \\
\hline 2006 & & & & $\mathrm{~V}$ \\
\hline 2007 & $62 / 61$ & & & $\mathrm{~V}$ \\
\hline 2008 & & & & $\mathrm{~V}$ \\
\hline 2009 & $62 / 62$ & $57 / 60$ & $40 / 37$ & $\mathrm{~V}$ \\
\hline 2010 & & $59 / 60$ & $40 / 37$ & $\mathrm{~V}$ \\
\hline 2011 & & $60 / 60$ & $-/ 40$ & $-/ 0$ \\
\hline 2012 & & $-/ \mathrm{x}$ & $-/ 40$ & $-/ 0$ \\
\hline 2013 & 62 & & & \\
\hline 2014 & 62.5 & & & \\
\hline 2015 & 62.5 & & & \\
\hline 2016 & 63 & & & \\
\hline
\end{tabular}

Notes: m: male; f: female, -: no early retirement; $\mathrm{x}$ : only for those, who have right of 40.

Table A3.2. Employment rate of population aged $15-74$ by selected age groups, $\%$

\begin{tabular}{c|c|c|c|c|c|c}
\hline & \multicolumn{3}{|c|}{ Males } & \multicolumn{3}{c}{ Females } \\
\hline Year & $55-59$ & $60-64$ & Total & $55-59$ & $60-64$ & Total \\
\hline 2010 & 56.3 & 16.5 & 54.2 & 46.6 & 9.5 & 43.6 \\
\hline 2011 & 56.9 & 17.4 & 55.0 & 49.9 & 11.0 & 43.7 \\
\hline 2012 & 61.2 & 17.0 & 55.7 & 49.7 & 11.2 & 44.9 \\
\hline 2013 & 64.9 & 21.1 & 57.4 & 51.4 & 11.1 & 45.4 \\
\hline 2014 & 70.6 & 26.9 & 60.8 & 56.8 & 13.4 & 48.0 \\
\hline
\end{tabular}

Source: Fazekas - Varga (2015, p. 221, Tables 4.13 and 4.14). 
Table A3.3. Nominal and real earnings

\begin{tabular}{l|c|c|c}
\hline Year & $\begin{array}{c}\text { Gross earnings } \\
\text { 000 HUFs }\end{array}$ & $\begin{array}{c}\text { Net earnings } \\
\text { 000 HUFs }\end{array}$ & $\begin{array}{c}\text { Consumer price index } \\
\text { (previous year) }\end{array}$ \\
\hline 2010 & 202.5 & 132.6 & 104.9 \\
\hline 2011 & 213.1 & 141.2 & 103.9 \\
\hline 2012 & 223.1 & 144.1 & 105.7 \\
\hline 2013 & 230.7 & 151.1 & 101.7 \\
\hline 2014 & 237.7 & 155.7 & 99.8 \\
\hline
\end{tabular}

Source: Fazekas - Varga (2015, p. 241, Table 6.1).

Table A3.4. Number of males and females at normal retirement age (2006-2014)

\begin{tabular}{l|c|c}
\hline \multirow{2}{*}{ Year } & \multicolumn{2}{|c}{ Number of persons ('000) } \\
\cline { 2 - 3 } & Males & Females \\
\hline 2006 & 51.9 & $60.8^{\mathrm{a}}$ \\
\hline 2007 & 50.3 & $60.3^{\mathrm{b}}$ \\
\hline 2008 & 47.4 & $64.3^{\mathrm{b}}$ \\
\hline 2009 & 51.0 & 63.7 \\
\hline 2010 & 55.0 & 68.8 \\
\hline 2011 & 57.4 & 71.1 \\
\hline 2012 & 60.3 & 73.7 \\
\hline 2013 & 60.6 & 74.7 \\
\hline 2014 & $59.4^{\mathrm{c}}$ & $73.6^{\mathrm{c}}$ \\
\hline
\end{tabular}

Notes: (a)-(b) The normal female retirement age was only 60 in 2006 and only 61 in 2007 and 2008 (see Table A3.1 above). (c) Unisex normal retirement age was already somewhat higher than 62 in 2014.

Table A3.5. Old-age pensioners: retirement ages and numbers: males, females and Females 40

\begin{tabular}{|l|c|c|c|c|c|c|}
\hline & \multicolumn{2}{|c|}{ Males } & \multicolumn{2}{c|}{ Females } & \multicolumn{2}{c|}{ Females 40 } \\
\hline Year & $\begin{array}{c}\text { Average } \\
\text { retirement } \\
\text { age (year) }\end{array}$ & Size '000 & $\begin{array}{c}\text { Average } \\
\text { retirement } \\
\text { age (year) }\end{array}$ & Size '000 & $\begin{array}{c}\text { Average } \\
\text { retirement } \\
\text { age (year) }\end{array}$ & Size '000 \\
\hline 2005 & 59.9 & 30.6 & 57.7 & 45.1 & & \\
\hline 2006 & 59.9 & 33.1 & 57.5 & 46.1 & & \\
\hline 2007 & 59.7 & 50.9 & 57.8 & 62.0 & & \\
\hline 2008 & 59.8 & 25.7 & 57.3 & 39.3 & & \\
\hline 2009 & 59.7 & 37.1 & 59.9 & 15.2 & & \\
\hline 2010 & 60.2 & 37.2 & 60.7 & 13.6 & & 27.6 \\
\hline 2011 & 60.3 & 43.2 & 58.5 & 84.9 & 57.6 & 54.7 \\
\hline 2012 & 62.0 & 22.0 & 59.1 & 53.6 & 57.8 & 26.6 \\
\hline 2013 & 62.2 & 21.6 & 59.5 & 40.6 & 57.8 & \\
\hline 2014 & 62.2 & 14.8 & 59.3 & 35.6 & 58.2 & 26.2 \\
\hline
\end{tabular}

Source: Fazekas - Varga (2015, p. 262, Table 11.5).

Note: The number for Females 40 in 2011 also contains those who retired earlier but were reclassified in 2011. 
Table A3.6. The size ('000) and benefits (HUF '000) of Hungarian males retired in 2011: retirement age and length of contribution

\begin{tabular}{l|c|c|c|c|c|c}
\hline \multirow{2}{*}{ Age } & \multicolumn{3}{|c|}{ Size and length of contribution } & \multicolumn{3}{c}{ Benefit and length of contribution } \\
\cline { 2 - 7 } & $35-39$ & $40-44$ & $\begin{array}{c}\text { (Total sample) } \\
\text { Total }\end{array}$ & $35-39$ & $40-44$ & $\begin{array}{c}\text { (Total sample) } \\
\text { Average }\end{array}$ \\
\hline $54-55$ & 0.7 & 0.3 & $\mathbf{1 . 9}$ & 100.3 & 108.4 & $\mathbf{8 8 . 5}$ \\
\hline $56-57$ & 0.7 & 1.1 & $\mathbf{2 . 5}$ & 108.6 & 113.2 & $\mathbf{9 9 . 9}$ \\
\hline $58-59$ & 1.1 & 6.3 & $\mathbf{9 . 2}$ & 112.5 & 116.6 & $\mathbf{1 1 4 . 0}$ \\
\hline 60 & 2.7 & 13.7 & $\mathbf{2 1 . 7}$ & 78.3 & 106.3 & $\mathbf{1 0 3 . 3}$ \\
\hline 61 & 0.3 & 1.2 & $\mathbf{1 . 8}$ & 80.1 & 157.9 & $\mathbf{1 3 8 . 8}$ \\
\hline $62-63$ & 1.7 & 1.7 & $\mathbf{9 . 2}$ & 79.0 & 176.0 & $\mathbf{9 4 . 2}$ \\
\hline Total & $\mathbf{8 . 0}$ & $\mathbf{2 4 . 2}$ & $\mathbf{5 5 . 9}$ & $\mathbf{8 9 . 9}$ & $\mathbf{1 1 6 . 8}$ & $\mathbf{9 9 . 8}$ \\
\hline
\end{tabular}

Source: ONYF (2012, p. 109, based on Table 9.1).

Table A3.7. The size ('000) and benefits (HUF '000) of Hungarian females retired in 2011: retirement age and length of contribution

\begin{tabular}{l|c|c|c|c|r|r|r|c}
\hline \multirow{2}{*}{ Age } & \multicolumn{4}{|c|}{ Size and length of contribution } & \multicolumn{4}{c}{ Benefit and length of contribution } \\
\cline { 2 - 9 } & $30-34$ & $35-39$ & $40-44$ & $\begin{array}{c}\text { (Total sample) } \\
\text { Total }\end{array}$ & $30-34$ & $35-39$ & $40-44$ & $\begin{array}{c}\text { (Total sample) } \\
\text { Average }\end{array}$ \\
\hline $54-55$ & 0.3 & 0.7 & 6.5 & $\mathbf{8 . 2}$ & 72.7 & 85.5 & 90.1 & $\mathbf{8 6 . 4}$ \\
\hline $56-57$ & 0.2 & 0.9 & 23.9 & $\mathbf{2 5 . 4}$ & 67.2 & 88.0 & 96.1 & $\mathbf{9 4 . 9}$ \\
\hline $58-59$ & 0.4 & 6.3 & 35.4 & $\mathbf{4 2 . 6}$ & 64.2 & 81.4 & 110.5 & $\mathbf{1 0 5 . 5}$ \\
\hline 60 & 0.2 & 0.4 & 1.2 & $\mathbf{1 . 9}$ & 57.9 & 81.4 & 149.5 & $\mathbf{1 2 2 . 2}$ \\
\hline 61 & 0.1 & 0.1 & 0.2 & $\mathbf{0 . 4}$ & 58.6 & 78.3 & 156.5 & $\mathbf{1 0 4 . 4}$ \\
\hline $62-63$ & 1.9 & 0.4 & 0.2 & $\mathbf{8 . 0}$ & 62.2 & 74.8 & 155.7 & $\mathbf{6 7 . 1}$ \\
\hline Total & $\mathbf{4 . 6}$ & $\mathbf{9 . 3}$ & $\mathbf{6 7 . 5}$ & $\mathbf{9 5 . 8}$ & $\mathbf{6 8 . 6}$ & $\mathbf{8 2 . 0}$ & $\mathbf{1 0 4 . 4}$ & $\mathbf{9 3 . 3}$ \\
\hline
\end{tabular}

Source: ONYF (2012, p. 110, based on Table 9.2). 